\title{
The Usage of Social Media for Higher Education Purposes
}

\author{
Tihana Babić \\ Algebra University College, Zagreb, Croatia \\ tihana.babic@algebra.hr \\ Gordana Vilović \\ Faculty of Political Science, University of Zagreb, Croatia \\ gordana.vilovic@fpzg.hr \\ Ljubica Bakić Tomić \\ University of Applied Sciences Baltazar Zaprešić, Croatia \\ ljbakictomic@bak.hr
}

\begin{abstract}
Summary
Social media today are an inevitable part of everyday life; networking of individuals and new ways of communication and interaction have emerged in the academic world. They are available 24 hours a day, 7 days a week across a range of devices and from different locations, thus depending only on the availability of the internet and the will of their users. By enabling the creation and sharing of information, ideas, and interests through virtual communities and networks, whose purpose is to turn communication into interactive dialogue, they have influenced society, economics, politics, science, and education. Students of today are generations who have started virtual life on social media since their early age and do not know the world where there are no computers, cell phones, and social media. Social media is an example of technology students have widely adopted, but the digital gap between students and their educational institutions is evident. Numerous researches show that there is a need for integration of social media into the teaching process because students experience them as self-explanatory. There are many advantages and positive effects on the teaching process, but teachers are less likely to use them because they are more focused on their shortcomings and dangers. The use of technology can be influenced by numerous factors, and the current study is conducted to identify the current status of teachers' usage of social media in higher education and detection of factors which influence the usage of social media in higher education. The questionnaire is based on the Unified Theory of Acceptance and Use of Technology named UTAUT model as a theoretical framework, and data is collected on a sample of teachers at the Algebra University College in Zagreb and the University of Applied Sciences Baltazar Zaprešić. This research is the first research conducted among the higher education teachers in the Republic of Croatia, concerned not only with the social media usage for the higher education purposes but also with factors that influence the willingness of higher education teachers to use social media for the higher education purposes.
\end{abstract}

Key words: social media, higher education, teachers, communication, UTAUT Model

\section{Introduction}

Social media sites (SMS) are based on Web 2.0 technology, enabling the creation and sharing of information, ideas, and interests across virtual communities and networks that aim to turn communication into interactive dialogue. There are 13 subtypes: blogs, microblogs, business, and social networking tools, collaborative projects, forums, photo sharing tools, business collaboration tools, product and service reviews, research networks, social games, photo/video sharing tools, and virtual worlds (Aichner, Jacob, 2015). They are available 24 hours a day, 7 days a week, across a range of devices and from different locations. Therefore, they depend only on the availability of the internet and the will of their users. They have influenced society, economy, politics, science, and education.

Students of today are members of a generation that, inherently, have grown up on social media. Moreover, they do not know a world where computers, cell phones, and social media do not exist. Social media is an example of technology that has been widely adopted by students and, 
consequently, has the potential to become a valuable resource for supporting educational communication and student collaboration with the faculty (Arsović, 2012). Nevertheless, numerous studies point to the digital gap between students and their educational institutions, as well as the trend towards non-adaptation of new technologies in higher education institutions; students are willing to use them, and faculty employees are not (Roblyer et al., 2010).

There is no universal point of view and "the jury hasn't reached a verdict yet" about the use of social media for higher education purposes. Although their influence can be seen as something that enriches and makes our lives easier, we may have a more pessimistic view, but what we certainly cannot do is ignore the changes that have taken place.

\section{Previous researches}

Social media sites (SNS) and their users are a frequent topic of research, both in Croatia and worldwide. Statistics show that in January 2018, there were $48 \%$ of active social media users signing up for social media services (Statista, 2018a). The power of social networking is so great that the number of active social media users worldwide will grow from the current 2.62 billion to 3.02 billion by 2021, which is about a third of the total Earth population (Statista, 2018b).

Research on the impact of social media is being conducted in all areas of human activity, and the academic environment is no exception. Research into computer-mediated communication and the possibilities of social media application in higher education are most often concerned with students' activities on social media (Vivian et al., 2014; Echeng et al., 2016), confirming that they represent a new generation of students who are gaining knowledge in new ways (Selwyn, 2011). Moreover, research goes to prove that students 'values often conflict with the traditional values of higher education institutions (Ulbrich et al., 2011).

Social media tools and applications are challenging the concept of formal education as we know it today (Selwyn, 2011), and the role of teachers is changing. Research conducted on the attitudes and experiences of social media integration into higher education institutions (Echeng et al. 2016; Josefsson, 2017) shows that there is a need to integrate social media into the teaching process (OkelloObura, 2015)- In addition, research is showing the numerous benefits and positive effects on the learning and teaching process(Alsolamy et al., 2017; Coleman et al., 2018) such as teaching quality (Silvestru et al., 2016) and students 'academic achievement (Tamayo et al., 2014). While students perceive social media as something self-explanatory, teachers are more inclined to reflect on the shortcomings and dangers (Raut et al., 2016; Willems et al., 2018).

\section{Unified theory of acceptance and use of technology (UTAUT model)}

The of usage of technology, in general, can be influenced by a number of factors, so in 2003 Venkatesh et al. developed and empirically validated a Unified Technology Acceptance and Use Theory (UTAUT) based on a review of 8 models of earlier theories and the consolidation of constructs. According to the UTAUT model (Venkatesh et al., 2003), behavioral intention (intention to use in the next 12-24 months) and (actual) behavior i.e. use of technology are distinguished. It is assumed that behavioral intention is significantly influenced by expected work performance, expected effort, and social impact, while behavioral intention and facilitating conditions significantly contribute to the actual use of the system. In addition to the predictors of use, four moderator variables of key relationships were included in the model: age, gender, the experience of use, and voluntary use. 


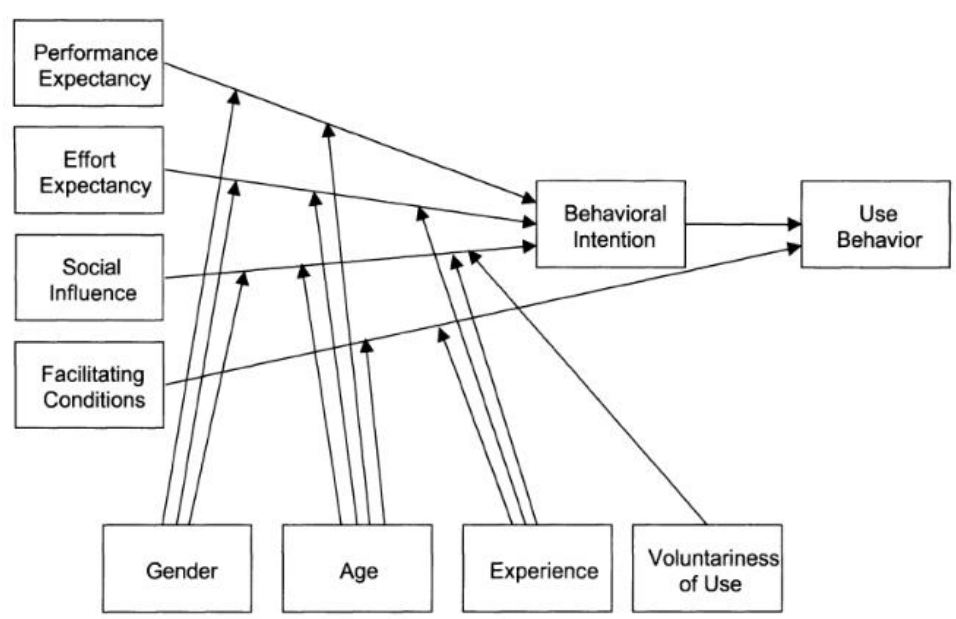

Figure 1. UTAUT Research Model (Venkatesh et al. 2003; 447)

The UTAUT model has different fields of application and has thus served as a theoretical basis for scientists in some countries to implement social computing in higher education institutions (Hussein, 2013) and to identify factors that influence students' use of social media platforms for academic purposes (Ali et al., 2017).

\section{The research goals}

The aim of the research was to determine and address whether teachers use social media for higher education purposes, and whether there is an influence of age, gender, scientific-teaching area and/or associate profession, teacher attitudes toward usage, social influence and anxiety when using social media to the actual teaching of usage of social media for higher education purposes.

The research questions are:

1. Do teachers use social media for higher education purposes?

2. Do demographic characteristics such as age, gender, and field of science of teaching and/or associate profession of teachers influence their use of social media for higher education purposes?

3. Do teachers' attitudes, social impact, and anxiety when using social media influence their usage of social media for higher education purposes?

\section{The research sample}

A sample of this research was pertinent. There were 73 participants which have scientific-teaching and associate titles and are employed as teachers or external teaching assistants at the Algebra University College Zagreb (52\% of respondents) and the Baltazar Zaprešić University of Applied Sciences (48\% of respondents).

\section{Research methodology}

To examine teachers' perceptions and usage of social media in higher education, a structured questionnaire was designed according to a tailored UTAUT model (Venkatesh et al., 2003). The model is adjusted in such a way that, with the following independent variables: age, gender, anxiety, and social impact on the social media usage for higher education, the conceptual model is expanded by 2 more variables: attitude towards the social media usage for higher education purposes and the scientific field of scientific-teaching or associate titles.

The survey was conducted during the summer semester of the 2018/2019 academic year and was conducted using a specially designed questionnaire in the Google Forms tool, which was distributed to teachers via e-mail. Respondents participation was voluntary and anonymous. The questionnaire consisted of two wholes of grouped closed-ended questions about general demographics and social media usage for higher education. To ensure a clear understanding of the term social media before the question, a descriptive definition of the term social media is specified in the questionnaire. 


\section{Results of an empirical study with discussion}

\section{Do teachers use social media for higher education purposes?}

The results of this study on teachers' social media usage for higher education purposes are presented concerning the frequency of use and subtypes of social media used by teachers.

\subsection{Frequency of teachers' social media usage for higher education purposes}

Table 1 shows that almost half of the respondents, $47.9 \%$ of them, use social media for higher education purposes daily, but less than an hour a day, while the smallest percentage (9.6\%) do so for several hours a day. $32.8 \%$ of respondents do this in the range of several hours per week to several hours per month, and $13.7 \%$ of respondents do not use social media at all.

Table 1. Distribution of the answer to the question $(N=73)$ : How often do you use social media for higher education purposes? Source: questionnaire and author's analysis.

\begin{tabular}{|l|l|}
\hline Using social media for higher education purposes & $\begin{array}{l}\text { Percentage of respondents in the } \\
\text { sample }\end{array}$ \\
\hline A few hours a day & $9.6 \%$ \\
\hline Less than an hour a day & $47.9 \%$ \\
\hline A few hours a week & $16.4 \%$ \\
\hline A few hours a month & $16.4 \%$ \\
\hline I don't use social media & $13.7 \%$ \\
\hline
\end{tabular}

\subsection{Social media subtypes used by teachers for higher education purposes}

Respondents indicated that they mostly use social networks such as Facebook, Google+ (49.3\%), social media for video sharing such as YouTube, Vimeo (46.6\%) and business networks such as LinkedIn (43.8\%) for higher education purposes, while least of them use social games such as World of Warcraft or Mafia Wars $(2.7 \%)$ or social media for bookmarking such as Pinterest and Reddit (12.3\%). 13.7\% of survey participants do not use any of the social media subtypes for higher education purposes.

\section{Impact of age, gender and scientific field of scientific-teaching and/or associate profession of teachers on their use of social media for higher education}

In the second part of the analysis, demographic differences in the total sample $(\mathrm{N}=73)$ were examined. The demographic statistics of the sample are shown in Table 2.

Table 2. Distribution of respondents by age, gender and scientific field of scientific-teaching and/or associate profession $(\mathrm{N}=73)$. Source: questionnaire and authors' analysis.

\begin{tabular}{|l|l|l|}
\hline Variable & Category & Percentage \\
\hline \multirow{4}{*}{ Gender } & Men & $56.2 \%$ \\
\cline { 2 - 3 } & Women & $43.8 \%$ \\
\hline & Less than 20 years & $0 \%$ \\
\cline { 2 - 3 } & $21-30$ years & $8.2 \%$ \\
\cline { 2 - 3 } & $31-40$ years & $39.7 \%$ \\
\cline { 2 - 3 } & $41-50$ years & $30.1 \%$ \\
\cline { 2 - 3 } & $51-60$ years & $13.7 \%$ \\
\cline { 2 - 3 } & 61 years and over & $8.2 \%$ \\
\hline \multirow{5}{*}{ Scientific area } & Natural Sciences & $13.7 \%$ \\
\cline { 2 - 3 } & Technical Sciences & $24.7 \%$ \\
\cline { 2 - 3 } & Biomedicine and Healthcare & $0 \%$ \\
\cline { 2 - 3 } & Biotehncical Sciences & $0 \%$ \\
\cline { 2 - 3 } & Social Sciences & $54.8 \%$ \\
\cline { 2 - 3 } & Human Sciences & $11 \%$ \\
\cline { 2 - 3 } & Art field & $4.1 \%$ \\
\cline { 2 - 3 } & Interdisciplinary fields & $15.1 \%$ \\
\hline
\end{tabular}


To answer the second research question, the following hypothesis is defined:

H1: There are statistically significant differences in the acceptance of the social media usage for the higher education purposes by students and teachers concerning the following indicators: age, gender and scientific area of scientific-teaching and/or associate profession.

The data were analyzed by chi-square test (Table 3$)$ and showed that the variables age $(p=0.341)$, gender $(\mathrm{p}=0.405)$ and scientific area $(\mathrm{p}=0.117)$ were not statistically significant for teachers' social media usage for higher education purposes and therefore hypothesis $\mathrm{H} 1$ is rejected.

Table 3. Indicators of age, gender and scientific area of scientific-teaching and/or associate profession; Pearson Chi-Square Test, Source: Questionnaire, SPSS Author Processing

\begin{tabular}{|l|l|l|l|}
\hline Indicator & Value & df & $\begin{array}{l}\text { Asymp. Sig. (2- } \\
\text { sided) }\end{array}$ \\
\hline Teacher gender & $4,008 \mathrm{a}$ & 4 & 405 \\
\hline Teacher age & 17,717 a & 16 &, 341 \\
\hline $\begin{array}{l}\text { Scientific area of scientific-teaching and/or associate profession of } \\
\text { teacher }\end{array}$ & $27,705 \mathrm{a}$ & 20 &, 117 \\
\hline
\end{tabular}

\section{The impact of teachers 'attitudes, social influence, and anxiety when using social media for higher education purposes}

3.1. Teachers' attitudes and social media usage for higher education purposes

To determine whether teachers' attitudes influence their actual social media usage for higher education purposes, the main hypothesis is defined:

$\mathrm{H} 2$ : The social media usage for higher education purposes is significantly influenced by the teacher's attitude towards social media usage for higher education.

The grouping variable "Attitude of teachers towards the social media usage" had 4 sub-variables, auxiliary hypotheses were defined, and the data were analyzed by chi-square test (Table 4):

$\mathrm{H} 2.1$. The social media usage for higher education purposes is significantly influenced by the ATTITUDES of teachers: "Teachers should use social media more actively to teach students."

The stated attitude is not statistically significant $(\mathrm{p}=0,120)$, auxiliary hypothesis $\mathrm{H} 2.1$. is discarded.

$\mathrm{H} 2.2$. The social media usage for higher education purposes is significantly influenced by the

ATTITUDE OF THE TEACHER: Institutions of higher education should adopt a policy of using social media for study purposes.

The stated attitude was not statistically significant $(\mathrm{p}=0.143)$, auxiliary hypothesis $\mathrm{H} 2.2$. is discarded.

H2.3. The social media usage higher education purposes are significantly influenced by the ATTITUDES OF THE TEACHER: Institutions of higher education should implement teacher education on social media usage.

The stated attitude was statistically significant $(\mathrm{p}=0.003)$, auxiliary hypothesis $\mathrm{H} 2.3$. is accepted.

$\mathrm{H} 2.4$. The social media usage for higher education purposes is significantly influenced by the ATTITUDE OF THE TEACHERS: Higher education institutions should educate students on social media usage.

The stated attitude is statistically significant $(\mathrm{p}=0.002)$, thus supporting hypothesis $\mathrm{H} 2.4$. is accepted.

Table 4. Attitude toward social media usage for higher education purposes; Pearson Chi-Square Test, Source: Questionnaire, SPSS Author analysis

\begin{tabular}{|l|l|l|l|}
\hline $\begin{array}{l}\text { Attitude toward social media usage for higher education } \\
\text { purposes }\end{array}$ & Value & Df & $\begin{array}{l}\text { Asymp. Sig. } \\
\text { (2-sided) }\end{array}$ \\
\hline Teachers should use social media more actively to teach students. & $22,782^{\mathrm{a}}$ & 16 &, 120 \\
\hline $\begin{array}{l}\text { Higher education institutions should adopt a policy of using social } \\
\text { media for study purposes. }\end{array}$ & $22,004^{\mathrm{a}}$ & 16 &, 143 \\
\hline Colleges should spend on educating teachers on social media usage. & $35,728^{\mathrm{a}}$ & 16 &, 003 \\
\hline
\end{tabular}


T. Babić, G. Vilović, Lj. Bakić Tomić. The Usage of Social Media...

\begin{tabular}{|l|l|l|l|}
\hline Colleges should spend on educating students on social media usage. & $36,903^{\mathrm{a}}$ & 16 &, 002 \\
\hline
\end{tabular}

It can be concluded that there is a statistically significant connection between the teachers' attitude that higher education institutions should educate both teachers and students on the social media usage and the actual teaching of social media usage for the higher education purposes.

\subsection{Anxiety when using social media and teaching of social media usage for higher education purposes}

To determine whether anxiety when using social media influences teachers' social media usage for higher education purposes, the following main hypothesis is defined:

H3: Teachers' social media usage for higher education needs is significantly influenced by the construct from the adapted UTAUT model: ANXIETY when using social media.

The grouping variable "Anxiety when using social media" had 4 sub-variables, auxiliary hypotheses defined, and a chi-squared test used for testing (Table 5):

H3.1. Teachers' social media usage for higher education is significantly influenced by: "Feeling concerned about the social media usage for higher education."

The sub variable is not statistically significant $(\mathrm{p}=0.424)$, auxiliary hypothesis H3.1. is discarded.

H3.2. Teachers' social media usage for higher education is significantly influenced by: "Feeling scared that he/she might lose a lot of information when using social media for higher education if he/she does something wrong."

The sub variable is not statistically significant $(\mathrm{p}=0.400)$, auxiliary hypothesis H3.2. is discarded.

H3.3. Teachers' social media usage for higher education is significantly influenced by: "The hesitation in using social media for higher education from fear of errors that cannot be corrected."

The sub-variable is not statistically significant $(\mathrm{p}=0.634)$, auxiliary hypothesis H3.3. rejects.

H3.4. Teachers' social media usage for higher education is significantly influenced by: "The feeling that using social media for higher education is a little scary."

The sub-variable is statistically significant $(\mathrm{p}=0.033)$, auxiliary hypothesis H3.4. accept.

Table 5. Anxiety while using social media for higher education purposes; results Pearson Chi-Square Test, Source: questionnaire, SPSS author analysis

\begin{tabular}{|l|l|l|l|}
\hline Anxiety while using social media for higher education purposes & Value & Df & $\begin{array}{l}\text { Asymp. Sig. } \\
\text { (2-sided) }\end{array}$ \\
\hline $\begin{array}{l}\text { Feeling concerned about using social media for higher education } \\
\text { purposes. }\end{array}$ & $16,427^{\mathrm{a}}$ & 16 &, 424 \\
\hline $\begin{array}{l}\text { Feeling scared that she could / could lose a lot of information when } \\
\text { using social media for higher education purposes if she did something } \\
\text { wrong. }\end{array}$ & $16,775^{\mathrm{a}}$ & 16 &, 400 \\
\hline $\begin{array}{l}\text { The hesitation of using social media for higher education purposes for } \\
\text { fear of errors that cannot be corrected. }\end{array}$ & $13,532^{\mathrm{a}}$ & 16 &, 634 \\
\hline $\begin{array}{l}\text { The feeling that using social media for higher education needs is a little } \\
\text { daunting. }\end{array}$ & $27,849 \mathrm{a}$ & 16 &, 033 \\
\hline
\end{tabular}

Based on the results, it can be concluded that there is a statistically significant connection between the teachers' sense that the social media usage for higher education is a bit scary and the actual teacher's social media usage for higher education purposes.

\subsection{Social influence and teachers' social media usage for higher education purposes}

To determine connection between social influence and teachers' social media usage for higher education purposes, the following main hypothesis is defined:

H4: The teachers' social media usage for higher education purposes is significantly influenced by the construct from the adapted UTAUT model: SOCIAL IMPACT.

The grouping variable "SOCIAL IMPACT" had 4 sub-variables, auxiliary hypotheses were defined, and a chi-squared test was used to test the auxiliary hypotheses (Table 6): 
H4.1. Teachers' social media usage for higher education is significantly influenced by: " Colleague teachers using social media for higher education."

The stated social influence was not statistically significant $(\mathrm{p}=0.127)$, auxiliary hypothesis H4.1. is discarded.

H4.2. Teachers' social media usage for higher education is significantly influenced by "Students who feel that teachers should use social media for higher education."

The stated social influence was statistically significant $(\mathrm{p}=0.035)$, auxiliary hypothesis H4.2. is accepted.

H4.3. Teachers' social media usage for higher education is significantly influenced by: "Friends and close acquaintances of teachers who use social media for higher education."

The indicated social influence was not statistically significant $(\mathrm{p}=0.348)$, ancillary hypothesis H4.3. is discarded.

H4.4. Teachers' social media usage for higher education is significantly influenced by "Faculty management that supports the use of social media for higher education purposes."

The indicated social influence is statistically significant $(\mathrm{p}=0.022)$, auxiliary hypothesis H4.4. is accepted.

Table 6. Social influence on using social media for higher education purposes; Pearson Chi-Square Test, Source: questionnaire, SPSS author analysis

\begin{tabular}{|l|l|l|l|}
\hline $\begin{array}{l}\text { Social influence on using social media for higher education } \\
\text { purposes }\end{array}$ & Value & Df & $\begin{array}{l}\text { Asymp. Sig. } \\
\text { (2-sided) }\end{array}$ \\
\hline $\begin{array}{l}\text { College teachers using social media for higher education } \\
\text { purposes. }\end{array}$ & $22,539^{\mathrm{a}}$ & 16 &, 127 \\
\hline $\begin{array}{l}\text { Students who feel that teachers should use social media for } \\
\text { higher education purposes. }\end{array}$ & $27,584^{\mathrm{a}}$ & 16 &, 035 \\
\hline $\begin{array}{l}\text { Friends and close acquaintances of teachers using social media } \\
\text { for higher education purposes. }\end{array}$ & $17,599^{\mathrm{a}}$ & 16 &, 348 \\
\hline $\begin{array}{l}\text { Faculty management that supports the use of social media for } \\
\text { higher education purposes. }\end{array}$ & $29,300^{\mathrm{a}}$ & 16 &, 022 \\
\hline
\end{tabular}

It can be concluded that there is a statistically significant connection between the influence of students who believe that teachers should use social media for higher education and the influence of the faculty administration that supports the social media usage for higher education on the actual teaching social media usage for higher education.

Finally, it can be pointed out that this research has shown that gender, age and the scientific field of teaching are not significantly affected by the actual social media usage of teachers, but it is certainly not neglected that there are statistically significant relationships between particular attitudes of teachers towards the social media usage. Social influences and variations in anxiety when using social media on actual teacher social media usage, as summarized in Table 7.

Table 7. Summary of Findings; Source: questionnaire, SPSS author analysis

\begin{tabular}{|l|l|l|}
\hline Dependent Variable & Independent Variables & Explanation \\
\hline $\begin{array}{l}\text { SMS usage for higher } \\
\text { education purposes }\end{array}$ & Gender & There is no statistically significant connection \\
\hline $\begin{array}{l}\text { SMS usage for higher } \\
\text { education purposes }\end{array}$ & Age & There is no statistically significant connection \\
\hline $\begin{array}{l}\text { SMS usage for higher } \\
\text { education purposes }\end{array}$ & Academic Field & There is no statistically significant connection \\
\hline $\begin{array}{l}\text { SMS usage for higher } \\
\text { education purposes }\end{array}$ & $\begin{array}{l}\text { Attitude toward using SNS } \\
\text { for higher education } \\
\text { purposes }\end{array}$ & $\begin{array}{l}\text { There is no statistically significant connection between: } \\
\text { Teachers should use social media more actively to teach } \\
\text { students. } \\
\text { Higher education institutions should adopt a policy of using } \\
\text { social media for study purposes. } \\
\text { There is a statistically significant connection between: } \\
\text { Colleges should spend on educating teachers on social media } \\
\text { usage. } \\
\text { Colleges should spend on educating students on social media }\end{array}$ \\
\hline
\end{tabular}


T. Babić, G. Vilović, Lj. Bakić Tomić. The Usage of Social Media...

\begin{tabular}{|l|l|l|}
\hline & & usage. \\
& & \\
\hline $\begin{array}{l}\text { SMS usage for higher } \\
\text { education purposes }\end{array}$ & Social Influence & $\begin{array}{l}\text { There is no statistically significant connection between: } \\
\text { College teachers using social media for higher education } \\
\text { purposes. } \\
\text { Friends and close acquaintances of teachers using social media } \\
\text { for higher education purposes. } \\
\text { There is a statistically significant connection between: } \\
\text { Students who feel that teachers should use social media for } \\
\text { higher education purposes. } \\
\text { Faculty managment that supports the use of social media for } \\
\text { higher education purposes. }\end{array}$ \\
\hline $\begin{array}{l}\text { SMS usage for higher } \\
\text { education purposes }\end{array}$ & $\begin{array}{l}\text { Computer Anxiety when } \\
\text { using fNS higher } \\
\text { education purposes }\end{array}$ & $\begin{array}{l}\text { There is no statistically significant connection between: } \\
\text { Feeling concerned about using social media for higher } \\
\text { education purposes. } \\
\text { Feeling scared that she could / could lose a lot of information } \\
\text { when using social media for higher education purposes if she } \\
\text { did something wrong. } \\
\text { The hesitation of using social media for higher education } \\
\text { purposes for fear of errors that cannot be corrected. } \\
\text { There is a statistically significant connection between: } \\
\text { The feeling that using social media for higher education } \\
\text { purposes is a little daunting. }\end{array}$ \\
\hline
\end{tabular}

\section{Conclusion}

This paper examines whether teachers' demographic characteristics, attitudes toward usage, social influences, and anxiety when using social media influence their actual social media usage for higher education purposes.

The results show that the age, gender and scientific field of the teaching profession do not affect their actual social media usage for higher education purposes, as is the case with particular attitudes towards use, social influences, and anxiety when using. However, it is not negligible that at the same time higher education institutions would have a significant and positive impact on their actual social media usage through the implementation of education for teachers and students on the social media usage, which could also reduce their sense that the social media usage for the needs of high education is little scary. For teachers' usage of social media for higher education purposes, significantly, students believe teachers should use social media for higher education purposes. Moreover, for them, support from faculty administration regarding social media usage for higher education is also crucial.

The research conducted has certain shortcomings as well that could be eliminated in future research. This research was conducted at two higher education institutions and thus the results of the research do not necessarily apply to other higher education institutions. Also, the sample was relatively small. The study included a limited number of relevant variables, and more accurate results could be obtained by examining the extent to which a single variable is statistically significant and to what extent it affects the behavior of teachers regarding the actual social media usage for higher education needs. Future research could extend the analysis to other variables such as the extent to which perceived strengths and perceived disadvantages affect the actual social media usage. The results can also be compared between private and public higher education institutions.

\section{References}

Ali, M., Yaacob, R.; Ednut, B., Makki, B. (2017). Determining the academic Use of Social Media with technology Acceptance Models. Pakistan: NFC Institute of Engineering and Fertilizer Research

Alsolamy, F. (2017). Social networking in higher education: academics' attitudes, uses, motivations, and concerns. Doctoral, Sheffield Hallam University 
Arsović, B. (2012). Društvene mreže - izazovi mogućnosti za obrazovanje. // Tehnika i informatika u obrazovanju: 4. Internacionalna konferencija, Čačak: Tehnički fakultet Čačak

Coleman, B.; Petitt, S.; Buning, M. (2018). Social Media Use in Higher Education: Do Members of the Academy Recognize Any Advantages? // The Journal of Social Media in Society 7, 1, 420-442

Echeng, R., Usoro, A., Ewuzie, I. (2016). Factors to Consider when Enhancing the Use of Web 2.0 Technologies in Higher Education: Students' and Lectures' Views for Quality Use. // International Journal of Digital Society 7, 1

Josefsson, P. (2017). Higher education meets private use of social media technologies. Doctoral, KTH Royal Institute of Technology

Mabić, M. (2014). Društvene mreže u obrazovanju: Što misle studenti Sveučilišta u Mostaru, Opatija: XXI. Međunarodni znanstveni skup Društvo i tehnologija - Dr. Juraj Plenković

Nikolić, G. (2013). Cjeloživotno učenje, potrebne promjene u obrazovanju odraslih. Opatija: predavanje na IV. Susretu ustanova za obrazovanje odraslih, Arhiva Zajednica ustanova za obrazovanje odraslih

Nikolić, G. (2014). Nove tehnologije donose promjene. // Andragoški glasnik 18, 2, 25-43

Okello-Obura, C. (2015). Web 2.0 technologies application in teaching and learning. // Library Philosophy and Practice 1248

Raut, V., Patil, P. (2016). Use of Social Media in Education: Positive and Negative impact on the students. // International Journal on Recent and Innovation Trends in Computing and Communication 4, 1, 281-285

Roblyer, M. D., McDaniel, M., Webb, M., Herman, J., Witty, J. V. (2010). Findings on Facebook in higher education: A comparison of college faculty and student uses and perceptions of social network sites. // Internet and Higher Education $13,134-140$

Selwyn, N. (2011). Social media in higher education. Education and Technology Continuum, London - New York.

Silvestru, C. I., Lupescu, M. E., Draistaru, A. S. (2016). The Impact of Using Social Media in Adult Education, Studies from Education and Society

Statista (2018a). https://www.statista.com/statistics/295660/active-social-media-penetration-in-european-countries/. (21.10.2018)

Statista (2018b). https://www.statista.com/topics/1164/social-networks/. (21.10.2018)

Sugimoto, C. R., Work, S., Lariviere, V., Haustein, S. (2016). Scholarly use of social media and altmetrics: a review of the literature. // Journal of the association for Information Science

Tamayo, J. D., Cruz, G. S. G. (2014). The Relationship of Social Media with the Academic Performance of Bachelor of Science in Information Technology Students of Centro Escolar University - Malolos. // International Journal of Scientific and Research Publications 4, 5, 1-9

Ulbrich, F., Jahnke, I. Martensson, P. (2011). Special Issue on knowledge development and the net generation. // International Journal of Sociotechnology and Knowledge Development

Venkatesh, V., Morris, M. G., Davis, G. B., Davis, F. D. (2003). User Acceptance of Information Technology: Toward a Unified View. MIS Quarterly 27, 3, 425-478

Vivian, R., Barnes, A., Geer, R., Wood, D. (2014). The academic journey of university students on Facebook: an analysis of informal academic-related activity over a semester // Association for learning technology: Open Access Journal

Willems, J., Adachi, C., Bussey, F., Doherty, I., Hujiser, H. (2018). Debating the use of social media in higher education in Australasia: Where are we now? // Australasian Journal of Educational Technology 34, 5 